the ground floor is a laboratory designed for the practical instruction of nearly sixty students entering upon the honours course in chemistry; the accessory accommodation comprises a glass workshop, a metal workshop, an instrument room, a room for preparing materials required in practical examinations, and a store from which materials needed in the department of inorganic and physical chemistry are issued. There is also a small lecture theatre and a laboratory reserved for food analysis, together with balance rooms, service rooms and staff rooms. The upper section of the new accommodation is on a floor provided at half the height of the old laboratory. It comprises a laboratory for general inorganic chemistry and advanced analysis, named the Crookes laboratory after the late Sir William Crookes, who entered the Royal College of Chemistry in 1848 and later held the post of assistant to Hofmann. The laboratory for advanced organic chemistry is named after the late Sir Edward Frankland, Hofmann's successor as professor of chemistry from 1865 until 1885, while that for advanced physical chemistry commemorates the many-sided services to the Imperial College of the late Prof. J. C. Philip, who retired from the directorship of the inorganic and physical chemistry laboratories in 1938 but was afterwards recalled to act for a time as deputy rector of the College. In his address, Lord Falmouth referred to the great importance of practical studies in these days of increasingly complex experimental techniques, and spoke appreciatively of the help that an active school of experimental science derives from the work of an enthusiastic and cooperative team of highly skilled technicians.

\section{Vacuum: A New Scientific Quarterly}

DURING the past thirty years the use of highvacuum techniques and processes has spread from the research laboratory to many branches of science and industry; references to the latest developments, however, are not easily found, for articles relating to vacuum technology are scattered indiscriminately throughout the seientific and technical literature under headings ranging from engineering to pathology. There is a definite need for a specialized journal which deals with the basic techniques, equipment and industrial applications of vacuum technology, and which collects from the various sources, into a convenient form, detailed information about new developments in this field. Messrs. W. Edwards and Co., Ltd., of London, the well-known manufacturers of vacuum equipment, are therefore to be congratulated for their foresight, and for their enterprise, in launching a new quarterly, Vacuum, the first journal in the English language to be devoted solely to vacuum research and engineering (1, No. 1, January 1951 ; pp. 72 ; 25s. a year). Though Vacuum, in addition to being published by a private company is also edited by $\mathrm{H}$. L. J. Burgess, a member of the staff of the same firm, it is intended to make it a strictiy impartial and authoritative scientific quarterly with contributions from various sources. The first number contains three original contributions, letters to the editor, book reviews, and a self-contained section, consisting of some forty pages, of classified abstracts of articles on subjects connected with vacuum technology. The leading article is by Prof. E. N. da C. Andrade, who reviews the growth and rapid development during recent years of the use of vacuum processes in research and industry. This is followed by a description by Dr. J. C. Harris, of the Chester Beatty
Research Institute, of the application of freeze. drying to the preservation of bacteria and viruses. The third original contribution is by L. Holland, of the research laboratories of Messrs. Edwards and Co., who summarizes the various methods and forms of apparatus used for the production by evaporation in vacuo of solid thin films and the properties and uses of such films. Special care has been taken in the classified abstract section to ensure that the section is as complete and comprehensive as possible. The abstracts are printed on one side of the paper only and are detachable ready for filing. They are arranged under four main group headings: general science and engineering, vacuum apparatus and auxiliaries, vacuum processing techniques and special subsidiary apparatus. There are also brief summaries of the abstracts in French.

\section{Rehabilitation}

THE first issue of a new series of the journal of the British Council for Rehabilitation contains an important article by Sir Harold Wiles on the industrial implications of rehabilitation. Sir Harold describes that part of the rehabilitation process which falls between the completion of active surgical or medical treatment for a particular condition, and the point at which a patient has become fit to start with confidence on doing a full day's work in employ. ment without any special conditions or, alternatively, to start on a full-time course of training to learn some vocational skill for a new kind of employment. In other articles Sir Henry Kessler considers recent achievements in rehabilitation, and Dr. Idris Davies the work of rehabilitation and resettlement which is being done with pneumoconiosis patients in South Wales, while Sheridan Russell examines the place for epileptics in industry. The journal also contains a report of a recent conference on cerebral palsy and an account of the Royal Air Force Medical Rehabilitation Unit at Headley Court, Surrey, as well as a summary of the recommendations drawn up by representatives of the Brussels Treaty countries for the rehabilitation of all disabled people. The journal will be published quarterly by the British Council for Rehabilitation, Tavistock House (South), Tavistock Square, London, W.C.1, price $2 s$.

\section{Giant Squid Stranded in Cornwall}

Av account of a female giant squid which was found in a live condition near Looe in November 1940 has been prepared by Dr. W. J. Rees (Bull. Brit. Mus., Nat. Hist., 1, No. 2, 29 ; 1950 ; 4s.). The overall length of this specimen (from apex to tip of right tentacle) was $1,860 \mathrm{~mm}$. It is interesting to note that this species is only known from strandings, and all those hitherto found have been females. A plot of the strandings of this species on the coasts of Britain shows that, except for the Looe specimen, all those previously recorded have been from Scotland and the north-east coast of England. Both Ommastrephes caroli and the related $O$. pteropus appear to be true oceanic species, and the catch by a trawler of a single specimen of the latter species in 180-200 fathoms off St. Kilda suggests that their true habitat is off the edge of the continental slope. Dr. Rees considers that they occasionally migrate into the North Sea in summer and are later enfeebled by unfavourable conditions during the winter months. It is only by such careful recording of these rarely found animals that one can begin to learn something of their distribution and habitats. 